Published in final edited form as:

Pharmacol Ther. 2016 February ; 158: 63-70. doi:10.1016/j.pharmthera.2015.11.013.

\title{
AKT signaling in ERBB2-amplified breast cancer
}

\author{
F Javier Carmona ${ }^{a}$, Filippo Montemurro ${ }^{b}$, Srinivasaraghavan Kannan ${ }^{c}$, Valentina Rossi ${ }^{d}$, \\ Chandra Vermac,e,f ${ }^{\mathrm{f}}$ José Baselga ${ }^{\mathrm{a}, \mathrm{g}}$, and Maurizio Scaltriti ${ }^{\mathrm{a}}$ \\ aMemorial Sloan Kettering Cancer Center (MSKCC), Human Oncology and Pathogenesis \\ Program (HOPP), New York, USA \\ bInstitute for Cancer Research and Treatment, Unit of Investigative Clinical Oncology, Candiolo, \\ Italy
}

'Bioinformatics Institute (A`STAR), \#07-01 Matrix, 30 Biopolis Street \#07-01, Singapore 138671

'Ospedale Civile di Saluzzo, Medical Oncology, Saluzzo, Italy

eDepartment of Biological Sciences, National University of Singapore, 14 Science Drive 4, Singapore 117543

fSchool of Biological Sciences, Nanyang Technological University, 60 Nanyang Drive, Singapore 637551

9Memorial Sloan Kettering Cancer Center, Department of Medicine, 1275 York Avenue, Box 20, New York, NY 10065

\begin{abstract}
The PI3K/AKT pathway is the focus of several targeted therapeutic agents for a variety of malignancies. In ERBB2-amplified breast cancer, the hyperactivation of this signaling cascade is associated with resistance to ERBB2-targeted therapy. This can occur through gain-of-function alterations or compensatory mechanisms that enter into play upon pharmacological pressure. The strong rationale in combining anti-ERBB2 agents with PI3K/AKT inhibitors, together with the identification of genomic alterations conferring sensitivity to targeted inhibition, are guiding the design of clinical studies aimed at preventing the emergence of drug resistance and achieving more durable response.

In the present review we describe the involvement of this pathway in breast cancer pathogenesis, with an emphasis on AKT kinases, and provide insight into currently available targeted agents for the treatment of ERBB2-amplified breast cancer. Finally, we provide preliminary data on a novel AKT3 mutation detected in the context of resistance to anti-ERBB2 therapy as an example of genomics-based approaches towards uncovering novel actionable targets in this setting.
\end{abstract}

Corresponding author: Maurizio Scaltriti, Ph.D., Memorial Sloan Kettering Cancer Center, Human Oncology \& Pathogenesis Program (HOPP), 1275 York Avenue, Box 20, New York (NY) 10065, Phone: +1 212-639-8000, scaltrim@ @skcc.org.

Conflicts of interest

Filippo Montemurro is a consultant for GlaxoSmithkline and Speaker's bureau for Astra Zeneca and Hoffmann La Roche.

Publisher's Disclaimer: This is a PDF file of an unedited manuscript that has been accepted for publication. As a service to our customers we are providing this early version of the manuscript. The manuscript will undergo copyediting, typesetting, and review of the resulting proof before it is published in its final citable form. Please note that during the production process errors may be discovered which could affect the content, and all legal disclaimers that apply to the journal pertain. 


\section{Keywords}

PI3K; mTOR; trastuzumab; targeted therapy; drug resistance; AKT3

\section{Introduction}

With over 20 years of research on its shoulders, the phosphatidylinositol 3-kinase (PI3K)/ Protein kinase $\mathrm{B}$ ( $\mathrm{PKB} / \mathrm{Akt})$ signaling pathway is one of the most intensely studied signaling networks in human cell biology and, in particular, in cancer (Chalhoub \& Baker, 2009). Through a tightly coordinated cascade of phosphorylation events, the components of this pathway integrate the signals from cell membrane receptors - receptor tyrosine kinases (RTKs) and G-protein-coupled receptors (GCPRs), among others, to regulate numerous cellular functions including cell survival, proliferation, metabolism, protein synthesis, transcription and cell death (Figure 1). Soon after its discovery, hyperactivation of the PI3K/AKT pathway was identified as a potent contributor to tumorigenesis in different cancer types, and prompted investigators to elucidate its mechanisms of action and regulation. Accordingly, in recent years, The Cancer Genome Atlas (TCGA) and other cancer-genome sequencing studies have uncovered a variety of alterations affecting different components of the pathway. Many of these have been recognized as oncogenic drivers and thus represent validated targets for the development of targeted therapies.

In breast cancer, hyperactivation of this cascade can occur upon amplification or gain-offunction mutations of RTKs such EGFR and ERBB2. Moreover, activating mutations in the PI3K/AKT pathway are frequent in this disease and have been related with resistance to both endocrine and anti-ERBB2 targeted therapies. Despite the fact that most of these mutations have been identified in PIK3CA, the gene encoding the catalytic subunit of PI3K, less frequent but functionally relevant alterations in other components of the pathway, such as AKT1, are attracting attention as putative mediators of tumor progression and drug resistance. In line with this, efforts have been made in developing specific PI3K/AKT inhibitors for cancer treatment that can be used alone or in combination with existing drugs.

This article will review the involvement of the PI3K/AKT pathway in ERBB2-amplified breast cancer, with a focus on the role of AKT as a central player in this signaling cascade. Moreover, we will summarize the current status of PI3K/AKT inhibitors under clinical development as single agents and in combination with ERBB2-targeted therapy. Finally, we will provide preliminary findings on a novel AKT3 mutation discovered in the context of resistance to anti-ERBB2 therapy.

\section{Structure and activity of the Protein Kinase B/AKT}

AKT is an evolutionary conserved serine-protein kinase belonging to the AGC subfamily of protein kinases that acts as a hub integrating numerous signaling inputs and controlling downstream effectors that maintain cell homeostasis. There are three highly conserved homologous isoforms: AKT1 (PKBa), AKT2 (PKB $\beta)$ and AKT3 (PKB $\gamma)$. Studies on isoform-specific functions have unveiled unique roles for each (Chen, et al., 2001; Cho, et al., 2001; Garofalo, et al., 2003; Tschopp, et al., 2005); however, phenotypic 
characterization of isogenic in vitro models revealed a certain degree of redundancy among the three isoforms, with all contributing to cellular fitness (Dummler \& Hemmings, 2007).

AKT consists of three conserved domains, an N-terminal pleckstrin homology (PH) domain connected through a linker region with a central kinase catalytic domain, and a short $\mathrm{C}$ terminal tail containing a regulatory hydrophobic motif (HM). Following recruitment to the plasma membrane -stimulated by RTK activation, for example, PI3K catalyzes the conversion of phosphatidylinositol 4, 5-bisphosphate $\left(\mathrm{PI}(4,5) \mathrm{P}_{2}\right)$ to the second messenger phosphatidylinositol 3, 4, 5-triphosphate $\left(\mathrm{PIP}_{3}\right)$. Accumulation of PI $(3,4,5) \mathrm{P}_{3}$ and, to a lesser extent, PI $(3,4) \mathrm{P}_{2}$, at the membrane induces the recruitment of AKT via its $\mathrm{PH}$ domain, and stimulates its catalytic activity through the activation of two regulatory sites: a threonine located in the activation T-loop (Franke, et al., 1995) - Thr308 (Akt1), Thr309 (Akt2) and Thr305 (Akt3) and phosphorylated by Phosphoinositide-Dependent Kinase 1 (PDK1), and a serine in the C-terminal hydrophobic motif - Ser473 (Akt1), Ser474 (Akt2) and Ser472 (Akt3) (Alessi, Andjelkovic, et al., 1996; Sarbassov, Guertin, Ali, \& Sabatini, 2005) and phosphorylated by the mammalian Target of Rapamycin (TOR) Complex mTORC2. Studies based on AKT crystal structures showed that the conformational change occurring upon dual phosphorylation unmasks the catalytic core and leads to an increase in its kinase activity by 1000-fold (Yang, et al., 2002). These phosphorylation events are required for full activity of the kinase. However, three complementary studies reported that PDK1 and mTORC2-mediated phosphorylation of the activation loop and the hydrophobic motif, respectively, are independent from each other and determine AKT substrate specificity (rather than its activity) (Frias, et al., 2006; Jacinto, et al., 2006; Shiota, Woo, Lindner, Shelton, \& Magnuson, 2006). These reports showed that AKT Thr308 phosphorylation was sustained in the absence of Ser473 phosphorylation. Interestingly, most of AKT downstream substrates remained phosphorylated in the absence of mTORC2 activity, indicating that mTORC2 was not upstream mTORC1. However, inhibitory phosphorylation of FoxO1 and FoxO3 transcription factors was impaired, suggesting a role for AKT phosphorylation status in determining its substrate selectivity.

AKT activity is modulated by lipid and protein phosphatases. Accumulation of lipid second messenger molecules $\left(\mathrm{PI}(3,4,5) \mathrm{P}_{3}\right.$ and $\left.\mathrm{PI}(3,4) \mathrm{P}_{2}\right)$ is opposed by the activity of phosphatase and tensin homolog (PTEN) (Myers, et al., 1998) and inositol polyphosphate 4-phosphatase type II (INPP4B) (Gewinner, et al., 2009) lipid phosphatases that catalyze PIP dephosphorylation and thus limit AKT recruitment to the plasma membrane. A second type of serine/threonine protein phosphatases directly controls AKT dual phosphorylation. Protein phosphatase 2A (PP2A) terminates AKT signaling by directly dephosphorylating the T308 residue in the activation loop (Andjelkovic, et al., 1996; Kuo, et al., 2008), whereas PH domain and leucine rich repeat protein phosphatases (PHLPP) 1 and 2 catalyze the dephosphorylation of S473 in the hydrophobic motif (Brognard, Sierecki, Gao, \& Newton, 2007). The activity of these phosphatases restraining PI3K/AKT activation is frequently lost or inactivated in human cancer, consistent with their tumor-suppressive function, causing an excessive accumulation of lipid second messenger at the inner membrane that in turn results in AKT hyperactivation (Figure 1). 


\section{Regulatory functions downstream of AKT}

Following membrane localization and phosphorylation by PDK1 and mTORC2, AKT is locked in the active conformation and diffuses across the cytoplasm and nucleus to phosphorylate a multitude of effectors involved in diverse functions. Studies on AKT isoform-specific knockout mice indicate that ubiquitously expressed AKT 1 and AKT 2 might promote cell survival and boost metabolism, respectively, whereas tissue-restricted AKT 3 expression would play a pivotal role in brain development (Chen, et al., 2001; Garofalo, et al., 2003; Tschopp, et al., 2005). A consensus motif R-X-R-X-X-S/T-F/L - X being any amino acid - is shared by direct substrates of AKT and provides specificity over other protein kinases within the same subfamily (Alessi, Caudwell, Andjelkovic, Hemmings, \& Cohen, 1996). To date, more than 100 AKT substrates involved in glucose metabolism, cell proliferation, survival and protein synthesis have been identified (reviewed in (Manning \& Cantley, 2007).

The first direct substrate identified was the serine/threonine glycogen synthase kinase 3 (GSK33) (Cross, Alessi, Cohen, Andjelkovich, \& Hemmings, 1995), described as a negative regulator of glycogen biosynthesis. In addition, inhibitory phosphorylation of GSK $3 \beta$ was shown to enhance proliferation by abating the inhibitory effect on pro-mitotic oncoprotein cyclin D1 (Diehl, Cheng, Roussel, \& Sherr, 1998). AKT-dependent phosphorylation has been shown to promote cell proliferation by means of inactivation of cell cycle checkpoint proteins such as p27 and p21 (Liang, et al., 2002; Shin, et al., 2002; Zhou, et al., 2001), and by enhancing mTORC1-dependent control of mRNA translation of oncoproteins that stimulate cell cycle progression (Gera, et al., 2004). mTORC1 activation is also central to anabolic processes underlying cell growth. Biosynthesis of proteins, lipids and nucleotides is increased by enhanced translation initiation and ribosome biogenesis (Chan, et al., 2011; Raught, et al., 2004; Thoreen, et al., 2012). AKT-dependent mTORC1 activation induces transcription machineries driving the expression of lipogenic enzymes involved in the synthesis of sterols and fatty acids (Sundqvist, et al., 2005) and promotes the production of ribose-5-phosphate required for nucleotide generation (Ben-Sahra, Howell, Asara, \& Manning, 2013). Furthermore, AKT signaling negatively regulates apoptosis by blocking the activity of pro-apoptotic factors such as Bax, Bad and Forkhead box O (FoxO) transcription factors (Brunet, et al., 1999), and activates pro-survival signaling pathways (Dan, et al., 2008).

\section{Molecular Alterations of AKT in Breast Cancer}

About 25\% of breast cancers exhibit mutations in PIK3CA. These frequently involve hotspots that are characterized by mutations on the helical (E545K, E542K) and kinase (H1047R) domains of the p110a catalytic subunit of PI3K. Data from 825 breast tumor samples analyzed by the TCGA showed that ERBB2-enriched samples, with a prevalence of ERBB2-amplified tumors, have a frequency of PIK3CA mutations of 39\% (Cancer Genome Atlas, 2012; Stephens, et al., 2012), causing hyperactivation of the PI3K enzyme and aberrant PI3K/AKT signaling. Of note, a recent report analyzing mutations and copy number alterations at single-cell resolution in ERBB2-amplified breast tumor samples has revealed that cells carrying mutations in PIK3CA often represent different clonal populations 
than those having ERBB2-copy gain within the same heterogeneous tumor (Janiszewska, et al., 2015). Despite these mutations were found to coexist within the same tumors, the frequency at which this occurs and the diversity of cellular subpopulations are not detected by bulk tumor sequencing at the coverage attained in the TCGA studies (Figure 2). The application of in situ sequencing techniques, therefore, may be a step forward to elucidate tumor heterogeneity and evolution under therapeutic pressure. In ERBB2-amplified breast cancer, AKT is also directly activated upon loss of PTEN and INPP4B lipid phosphatases (Gewinner, et al., 2009; Juric, et al., 2015) or mutations and copy-number alterations of AKT isoforms (Figure 2). The most frequent AKT mutation is found in the PH domain of AKT1 where a glutamic acid is substituted with a lysine residue at amino acid 17 (E17K) (Carpten, et al., 2007), resulting in enhanced activity of the kinase. In general, these mutations tend to be mutually exclusive with PIK3CA alterations or PTEN loss, suggesting functional redundancy in activating downstream signaling and inducing oncogenic transformation. Less common non-hotspot mutations in AKT1 with varying transforming potential have been reported in human breast cancers (Yi, Axtmayer, Gustin, Rajpurohit, \& Lauring, 2013). AKT3 is the most frequently amplified AKT isoform in breast cancer, and has been mostly studied in the triple-negative subtype in the context of resistance to therapy (Chin, et al., 2014) (Figure 2). Its role in ERBB2-amplified disease remains only partially understood.

\section{Rationale for the inhibition of the PI3K/AKT pathway in ERBB2-amplified breast cancer}

Fifteen years ago ERBB2 amplification/overexpression, present in $~ 20 \%$ of breast cancers, correlated with a very poor prognosis (Slamon, et al., 1987; Slamon, et al., 1989). The discovery and clinical development of ERBB2-targeted therapies have radically changed the management of this malignancy, now curable in the majority of cases diagnosed with local disease. Once spread to distant metastases, however, these tumors show high rates of drug resistance and, even if initially sensitive to anti-ERBB2 therapy, almost invariably recur.

As a common denominator, factors associated with resistance to ERBB2-targeted agents have been invariably associated with a reactivation of the PI3K/AKT/mTOR signaling cascade. Decreased levels of the tumor suppressor PTEN or activating mutations in PIK3CA have been shown to limit the response to ERBB2-targeted agents in pre-clinical models (Berns, et al., 2007; Eichhorn, et al., 2008; Kataoka, et al., 2010; Nagata, et al., 2004). In the clinic, while PIK3CA mutations were confirmed to be predictive of response (Juric, et al., 2015; Majewski, et al., 2015), loss of PTEN expression failed to do so (Nuciforo, et al., 2015).

Moreover, inhibition of ERBB2, PI3K or AKT was shown to lead to compensatory FOXOdependent RTK expression (Chandarlapaty, et al., 2011; Garrett, et al., 2011; Sergina, et al., 2007). A genetic functional approach in ERBB2-overexpressing cell lines showed that PTEN loss or gain-of-function E545K and H1047R PIK3CA mutations resulted in sustained AKT activation despite the presence of the ERBB2 kinase inhibitor lapatinib; yet combination with the dual PI3K/mTOR inhibitor NVP-BEZ235 was able to abrogate AKT phosphorylation and tumor growth (Eichhorn, et al., 2008). Moreover, similar results were 
obtained when combining the dual PI3K/mTOR inhibitor NVP-BEZ235 with trastuzumab in trastuzumab-resistant xenograft models (Serra, et al., 2011).

As a result, the PI3K/AKT pathway became an attractive target for therapeutic intervention with a plethora of agents currently under investigation and clinical development. The first compounds targeting this pathway were everolimus and temsirolimus (Table 1), mTOR allosteric inhibitors that, by interfering with mTOR complex 1 (mTORC1) activity, result in inhibition of cell cycle progression and survival. Everolimus was tested in ERBB2-amplified advanced breast cancer patients progressing to trastuzumab (Morrow, et al., 2011). In combination with trastuzumab, everolimus resulted in improved clinical benefits and increased progression-free survival (PFS), suggesting that mTOR inhibition could delay the emergence of resistance to anti-ERBB2 therapy. Confirmation of these early encouraging results was sought in two randomized clinical trials in HER2-positive metastatic breast cancer patients (Andre, et al., 2014; Hurvitz, et al., 2015). In the BOLERO-3 trial everolimus was added to trastuzumab and vinorelbine in patients with trastuzumab-resistant disease and yielded a statistically significant but small and transient PFS advantage. In the more recently published BOLERO- 1 trial, everolimus was added to paclitaxel and trastuzumab as first-line treatment and resulted in no efficacy on the co-primary end-point of PFS in the overall population. No survival advantage was seen in patients receiving everolimus in these two trials. A potential treatment by hormone-receptor status on PFS was consistently reported, suggesting meaningful activity of everolimus in patients with hormone-receptor negative disease. Furthermore, combined biomarker analysis of the BOLERO- 1 and 3 trials confirmed that the activity of everolimus seems to be confined to tumors showing evidence of "hyperactivity" of the PI3K pathway (Slamon, et al., 2015). These data suggest that targeting mTOR is potentially effective in a subset of HER2-positive patients, but also that compensatory pathways that have been well documented experimentally may limit the efficacy of this strategy.

Although treatment with allosteric inhibitors effectively target mTORC1 activity, it relieves a feedback inhibition of AKT leading to compensatory pathway activation and loss of therapeutic effectiveness (O'Reilly, et al., 2006). Aiming to overcome this problem, a number of mTOR ATP-competitive inhibitors have been developed; some of which are under clinical development (U. Banerji, 2012; Varga, 2013).

In ERBB2-amplified breast cancer, multiple PI3K or AKT inhibitors are currently under pre-clinical or clinical investigation. Isoform-specific or pan-PI3K inhibitors show activity in inhibiting PIK3CA-mutated cell lines, and responses have been documented in early phase clinical trials in solid tumors (Bendell, et al., 2012). Class I PI3K inhibitor BKM120 has shown activity in ERBB2-positive cell lines and xenograft models (Nanni, et al., 2012). GDC0941, also a pan PI3K inhibitor, suppresses proliferation in ERBB2-amplified in vitro models (Wallin, et al., 2012) and is currently under clinical evaluation in ERBB2-amplified metastatic breast cancer progressing to trastuzumab-based therapy (Table 1).

PI3K p110a specific inhibitor BYL719 exhibited enhanced activity on a large panel of PIK3CA-mutated and ERBB2-amplified breast cancer cell lines (Huang, 2012), and is being tested in combination with anti-ERBB2 and anti-HER3 therapy in patients with metastatic 
ERBB2-positive breast cancer (Shah, 2015). Similarly, breast cancer cell lines and xenograft models harboring mutations in PIK3CA or amplification of ERBB2 were found to be sensitive to p110ß-sparing PI3K inhibitor GDC-0032 in combination with trastuzumab or TDM1 (Sampath, 2013), and provided the rationale for its ongoing clinical evaluation in combination with anti-ERBB2 therapies.

Finally, catalytic (e.g. AZD5363, GDC-0068) and allosteric (MK-2206) inhibitors of AKT are also being investigated in preclinical and clinical settings (Table 1). In vitro, these compounds have shown enhanced activity in PIK3CA-mutant and PTEN-deficient experimental models, and showed growth inhibition in xenografts (Davies, et al., 2012; Sangai, et al., 2012; Tao, et al., 2014). Catalytic AKT inhibitors have shown activity in cell lines harboring AKT1 activating mutations (Carpten, et al., 2007) or oncogenic AKT3MAGI gene fusions (S. Banerji, et al., 2012). These experimental evidences have fostered the design of trials aimed to test their efficacy in patients as single agents (U. Banerji, 2013; Yan, et al., 2013) or in combination with other therapeutic regimes (H. S. Han, 2011; Michalarea, 2015).

Because of the involvement of the PI3K/Akt pathway in several physiological processes, including energy metabolism, it is no surprise that the potential clinical benefits of these drugs come at the cost of increased side effects (reviewed in (Chia, et al., 2015)). Some of these (e.g. hyperglycemia and cutaneous rash) are common to different drugs targeting the pathway; others are more typical of specific classes of compounds. For example, pan-PI3K inhibitors are associated with neutropenia, gastrointestinal side effects and mood disorders whereas stomatitis and non-infectious pneumonitis are more commonly observed in patients treated with mTOR inhibitors. The increasing clinical experience with these agents, however, resulted in a more proactive attitude of oncologists towards specific toxicities and the proportion of patients who need to discontinue treatment because of safety issue is reasonably small.

\section{AKT Alterations in breast cancer and resistance to anti-ERBB2 therapy}

Molecular profiling of tumor samples in recent years has uncovered a series of alterations affecting the AKT family members in breast cancer. Specifically, a hot-spot oncogenic somatic mutation $(\mathrm{E} 17 \mathrm{~K})$ affecting the region encoding the pleckstrin homology domain (PHD) of AKT1 was identified in breast, colorectal and ovarian cancers (Carpten, et al., 2007). Structurally, the lysine (K) substitution for glutamic acid (E) at amino acid 17 alters the conformation of the phosphoinositide-binding pocket resulting in an increased affinity for $\mathrm{PI}(4,5) \mathrm{P}_{2}$ and $\mathrm{PI}(3,4,5) \mathrm{P}_{3}$. This leads to a constitutive membrane localization of the kinase and increased phosphorylation on T308 and S473 in a PI3K-independent manner (Carpten, et al., 2007; Kumar \& Purohit, 2013; Landgraf, Pilling, \& Falke, 2008). At the functional level, the augmented localization of AKT at the plasma membrane is sufficient to transform cells in vitro and induce leukemia in mice transduced with the human $\mathrm{AKT1}{ }^{\mathrm{E} 17 \mathrm{~K}}$ allele (Cancer Genome Atlas, 2012; De Marco, et al., 2015). Subsequent analyses of cancer genomes indicated that the $\mathrm{AKT} 1{ }^{\mathrm{E} 17 \mathrm{~K}}$ mutation is present in other tumor types, but is more frequently detected in invasive breast carcinoma with an overall somatic mutation rate of $2.5 \%$ (TCGA results from 1098 patients). This mutation is restricted to the ductal and 
lobular subtypes and is (usually) mutually exclusive with the presence of activating mutations in PIK3CA, (TCGA, 2015 in preparation; (Bleeker, et al., 2008).

Moreover, several additional somatic mutations involving the PHD-kinase domain interface of AKT1 (L52R and D323H) detected in clinical specimens were shown to mediate tumor formation in vivo (Parikh, et al., 2012). Previous studies have shown that AKT allosteric inhibitors (e.g.: MK2206) bind to the closed PHD conformation, and thus genomic mutations altering this configuration reduce sensitivity to these compounds. However catalytic AKT inhibitors (e.g.: GDC0068, AZD5363) retain their activity and effectively inhibit AKT signaling. Accordingly, the TCGA data shows a prevalence of mutations involving the PHD as compared to other protein domains suggesting that genomic alterations perturbing the native conformation of this domain might be a mechanism of oncogenic AKT1 activation. These findings indicate that the mutational status of AKT has crucial clinical implications when selecting for appropriate therapeutic regimes.

Although infrequently $(<0.5 \%)$ mutated in breast tumors, a recent study identified an equivalent mutation on AKT2 (Stephens, et al., 2012). Unlike AKT1, AKT2 copy number variations are relatively frequent in breast cancer and other cancer types (Bellacosa, et al., 1995). Results from the TCGA indicate that this gene is amplified in 1.7-2.8\% of invasive breast carcinomas - co-occurring with ERBB2-amplification in some cases, and has been correlated with an increased incidence of pulmonary dissemination using either cell line models (Arboleda, et al., 2003) or an engineered mouse model of ERBB2-driven breast cancer (Dillon, et al., 2009).

Recent sequencing studies, however, revealed that the most frequently amplified isoform of AKT is AKT3 (TCGA Nature 2015, in preparation). AKT3 overexpression has been previously associated with metastatic dissemination in triple-negative breast cancers (Nakatani, et al., 1999) and was proposed as a therapeutic target in this subtype (Chin, et al., 2014). The effects of AKT3 activation in ERBB2-positive breast cancer has been recently examined using Balb-neuT ERBB2-driven transgenic mouse model (Grabinski, et al., 2014). In this study, the authors conclude that AKT3 is a crucial mediator of cell proliferation, and its genetic depletion causes FOXO3a-mediated estrogen receptor (ER)a upregulation and tamoxifen sensitivity, consistent with a crosstalk between the ERBB2 and ER pathways (Grabinski, et al., 2014; Hurtado, et al., 2008). Concurring with these findings, tumorsequencing data has also revealed that AKT3 amplification is found in a subset of ERBB2amplified breast cancer patients, suggesting that this isoform could represent a valid therapeutic target in this setting.

\section{A novel AKT3 mutation involved in acquired resistance to ERBB2-targeted therapy}

The emergence of AKT mutations as a mechanism of pathway reactivation in response to therapeutic agents has not yet been documented. In our laboratory we have recently identified a novel AKT3 mutation in a lesion resected from an ERBB2-amplified breast cancer patient treated with trastuzumab monotherapy (Carmona, 2014). After complete and durable tumor remission during trastuzumab monotherapy, the patient progressed in a 
subclavicolar lymph node, which was surgically removed and submitted for genomic analysis. Targeted exome-sequencing of this sample revealed that the acquisition of drug resistance coincided with the appearance of a missense mutation in AKT3 causing a single amino acid substitution in position 247 (R247C) that was not present in the lesion prior to treatment initiation. Importantly, given that the patient did not receive concomitant chemotherapy, the emergence of this mutation is only imputable to the pharmacological pressure associated with the anti-ERBB2 therapy. The substitution of an arginine with a cysteine within the kinase domain of the protein appears to affect the structure of the protein (Figure 3A-C) in a way that favors a conformational shift towards its active state that in turn may stimulate activation of the pathway (Figure 3D). Molecular modeling and simulations (details to be presented elsewhere) suggest that the mutation from R247 to C247 leads to loss of stabilizing interactions made by R247. This results in the destabilization of the inactive conformational state and shifts the population of the kinase conformations towards the active state. Cell proliferation assays show that ERBB2-overexpressing cells transduced with an $\mathrm{AKT} 3^{\mathrm{R} 247 \mathrm{C}}$ mutant $\mathrm{cDNA}$ exhibit enhanced mTORC1 activity and increased tolerance to trastuzumab when compared with untransfected or wild-type AKT3-transduced cells (Figure 3C), further suggesting that $\mathrm{AKT}^{\mathrm{R} 247 \mathrm{C}}$ could have causative role in the acquisition of resistance to anti-ERBB2 therapy. Immunostaining of histologic sections from the pre-treatment and post-treatment biopsies shows strong phospho-S6 staining (Figure 3D), indicative of mTOR pathway activation that could be attributed to increased AKT activity. Further experimental evidences are needed to assess the causal role of AKT3R247C in promoting mTORC 1 activity. These preliminary results entail important clinical implications since, if confirmed in additional patients, they would provide the rationale to administer a catalytic AKT inhibitor (e.g.: GDC-0068 or AZD5363) in this setting. Combined inhibition of AKT and ERBB2 has already been tested and showed promising activity in an unselected patient population (H. S. Han, et al., 2011). However, the potential of this therapeutic approach would be more effective if $\mathrm{AKT} 3^{\mathrm{R} 247 \mathrm{C}}$ and/or other biomarkers can identify a subset of patients exquisitely susceptible to dual AKT/ERBB2 blockade.

\section{Conclusions}

Molecular screening of patient samples using high-throughput profiling platforms is starting to guide the choice of therapeutic intervention. The criteria for establishing therapy regimes are switching from histopathologic biomarkers to dominant oncogenic alterations. Given the validity of the PI3K/AKT/mTOR axis as a pharmacological target in ERBB2-positive breast cancer, it is expected that patients with tumors harboring specific alterations in this pathway would benefit from PI3K/AKT inhibitors combined with anti-ERBB2 therapy. Ongoing and future clinical studies will likely provide insights for patient stratification and clinical management of HER2-positive breast cancer.

\section{Acknowledgments}

Financial Support

This work was founded by a NCI grant (R03CA187094-01), the Breast Cancer Research Foundation and the Geoffrey Beene Cancer Research Center. F Javier Carmona is recipient of a fellowship from the Terri Brodeur Breast Cancer Foundation (TBBCF). Filippo Montemurro is recipient of FPRC (onlus) 5 X 1000 Fondi Ministero della Salute 2012. Srinivasaraghavan Kannan and Chandra Verma are supported by BMSI, A*STAR, Singapore. 


\section{References}

Alessi DR, Andjelkovic M, Caudwell B, Cron P, Morrice N, Cohen P, Hemmings BA. Mechanism of activation of protein kinase B by insulin and IGF-1. EMBO J. 1996; 15:6541-6551. [PubMed: 8978681]

Alessi DR, Caudwell FB, Andjelkovic M, Hemmings BA, Cohen P. Molecular basis for the substrate specificity of protein kinase B; comparison with MAPKAP kinase-1 and p70 S6 kinase. FEBS Lett. 1996; 399:333-338. [PubMed: 8985174]

Andjelkovic M, Jakubowicz T, Cron P, Ming XF, Han JW, Hemmings BA. Activation and phosphorylation of a pleckstrin homology domain containing protein kinase (RAC-PK/PKB) promoted by serum and protein phosphatase inhibitors. Proc Natl Acad Sci U S A. 1996; 93:5699_ 5704. [PubMed: 8650155]

Andre F, O’Regan R, Ozguroglu M, Toi M, Xu B, Jerusalem G, Masuda N, Wilks S, Arena F, Isaacs C, Yap YS, Papai Z, Lang I, Armstrong A, Lerzo G, White M, Shen K, Litton J, Chen D, Zhang Y, Ali S, Taran T, Gianni L. Everolimus for women with trastuzumab-resistant, HER2-positive, advanced breast cancer (BOLERO-3): a randomised, double-blind, placebo-controlled phase 3 trial. Lancet Oncol. 2014; 15:580-591. [PubMed: 24742739]

Arboleda MJ, Lyons JF, Kabbinavar FF, Bray MR, Snow BE, Ayala R, Danino M, Karlan BY, Slamon DJ. Overexpression of AKT2/protein kinase Bbeta leads to up-regulation of beta1 integrins, increased invasion, and metastasis of human breast and ovarian cancer cells. Cancer Res. 2003; 63:196-206. [PubMed: 12517798]

Banerji S, Cibulskis K, Rangel-Escareno C, Brown KK, Carter SL, Frederick AM, Lawrence MS, Sivachenko AY, Sougnez C, Zou L, Cortes ML, Fernandez-Lopez JC, Peng S, Ardlie KG, Auclair D, Bautista-Pina V, Duke F, Francis J, Jung J, Maffuz-Aziz A, Onofrio RC, Parkin M, Pho NH, Quintanar-Jurado V, Ramos AH, Rebollar-Vega R, Rodriguez-Cuevas S, Romero-Cordoba SL, Schumacher SE, Stransky N, Thompson KM, Uribe-Figueroa L, Baselga J, Beroukhim R, Polyak K, Sgroi DC, Richardson AL, Jimenez-Sanchez G, Lander ES, Gabriel SB, Garraway LA, Golub TR, Melendez-Zajgla J, Toker A, Getz G, Hidalgo-Miranda A, Meyerson M. Sequence analysis of mutations and translocations across breast cancer subtypes. Nature. 2012; 486:405-409. [PubMed: 22722202]

Banerji U. First-in-human phase I trial of the dual mTORC1 and mTORC2 inhibitor AZD2014 in solid tumors. 2012 ASCO Annual Meeting. J Clin Oncol. 2012; 30(suppl):abstr 3004.

Banerji, U. Results of two phase I multicenter trials of AZD5363, an inhibitor of AKT1, 2 and 3: Biomarker and early clinical evaluation in Western and Japanese patients with advanced solid tumors. Cancer Res; AACR 104th Annual Meeting; 2013. p. Abstract nr LB-66

Bellacosa A, de Feo D, Godwin AK, Bell DW, Cheng JQ, Altomare DA, Wan M, Dubeau L, Scambia G, Masciullo V, Ferrandina G, Benedetti Panici P, Mancuso S, Neri G, Testa JR. Molecular alterations of the AKT2 oncogene in ovarian and breast carcinomas. Int J Cancer. 1995; 64:280285. [PubMed: 7657393]

Ben-Sahra I, Howell JJ, Asara JM, Manning BD. Stimulation of de novo pyrimidine synthesis by growth signaling through mTOR and S6K1. Science. 2013; 339:1323-1328. [PubMed: 23429703]

Bendell JC, Rodon J, Burris HA, de Jonge M, Verweij J, Birle D, Demanse D, De Buck SS, Ru QC, Peters M, Goldbrunner M, Baselga J. Phase I, dose-escalation study of BKM120, an oral panClass I PI3K inhibitor, in patients with advanced solid tumors. J Clin Oncol. 2012; 30:282-290. [PubMed: 22162589]

Berns K, Horlings HM, Hennessy BT, Madiredjo M, Hijmans EM, Beelen K, Linn SC, GonzalezAngulo AM, Stemke-Hale K, Hauptmann M, Beijersbergen RL, Mills GB, van de Vijver MJ, Bernards R. A functional genetic approach identifies the PI3K pathway as a major determinant of trastuzumab resistance in breast cancer. Cancer Cell. 2007; 12:395-402. [PubMed: 17936563]

Bleeker FE, Felicioni L, Buttitta F, Lamba S, Cardone L, Rodolfo M, Scarpa A, Leenstra S, Frattini M, Barbareschi M, Grammastro MD, Sciarrotta MG, Zanon C, Marchetti A, Bardelli A. AKT1(E17K) in human solid tumours. Oncogene. 2008; 27:5648-5650. [PubMed: 18504432]

Brognard J, Sierecki E, Gao T, Newton AC. PHLPP and a second isoform, PHLPP2, differentially attenuate the amplitude of Akt signaling by regulating distinct Akt isoforms. Mol Cell. 2007; 25:917-931. [PubMed: 17386267] 
Brunet A, Bonni A, Zigmond MJ, Lin MZ, Juo P, Hu LS, Anderson MJ, Arden KC, Blenis J, Greenberg ME. Akt promotes cell survival by phosphorylating and inhibiting a Forkhead transcription factor. Cell. 1999; 96:857-868. [PubMed: 10102273]

Cancer Genome Atlas N. Comprehensive molecular portraits of human breast tumours. Nature. 2012; 490:61-70. [PubMed: 23000897]

Carmona, F. AKT3 activation mediates resistance to HER2-targeted therapies in HER2-amplified breast cancer. European Journal of Cancer; 26th EORTC-NCI-AACR Symposium on Molecular Targets and Cancer Therapeutics; 2014. p. 50

Carpten JD, Faber AL, Horn C, Donoho GP, Briggs SL, Robbins CM, Hostetter G, Boguslawski S, Moses TY, Savage S, Uhlik M, Lin A, Du J, Qian YW, Zeckner DJ, Tucker-Kellogg G, Touchman J, Patel K, Mousses S, Bittner M, Schevitz R, Lai MH, Blanchard KL, Thomas JE. A transforming mutation in the pleckstrin homology domain of AKT1 in cancer. Nature. 2007; 448:439-444. [PubMed: 17611497]

Chalhoub N, Baker SJ. PTEN and the PI3-kinase pathway in cancer. Annu Rev Pathol. 2009; 4:127150. [PubMed: 18767981]

Chan JC, Hannan KM, Riddell K, Ng PY, Peck A, Lee RS, Hung S, Astle MV, Bywater M, Wall M, Poortinga G, Jastrzebski K, Sheppard KE, Hemmings BA, Hall MN, Johnstone RW, McArthur GA, Hannan RD, Pearson RB. AKT promotes rRNA synthesis and cooperates with c-MYC to stimulate ribosome biogenesis in cancer. Sci Signal. 2011; 4:ra56. [PubMed: 21878679]

Chandarlapaty S, Sawai A, Scaltriti M, Rodrik-Outmezguine V, Grbovic-Huezo O, Serra V, Majumder PK, Baselga J, Rosen N. AKT inhibition relieves feedback suppression of receptor tyrosine kinase expression and activity. Cancer Cell. 2011; 19:58-71. [PubMed: 21215704]

Chen WS, Xu PZ, Gottlob K, Chen ML, Sokol K, Shiyanova T, Roninson I, Weng W, Suzuki R, Tobe K, Kadowaki T, Hay N. Growth retardation and increased apoptosis in mice with homozygous disruption of the Akt1 gene. Genes Dev. 2001; 15:2203-2208. [PubMed: 11544177]

Chia S, Gandhi S, Joy AA, Edwards S, Gorr M, Hopkins S, Kondejewski J, Ayoub JP, Califaretti N, Rayson D, Dent SF. Novel agents and associated toxicities of inhibitors of the pi3k/Akt/mtor pathway for the treatment of breast cancer. Curr Oncol. 2015; 22:33-48. [PubMed: 25684987]

Chin YR, Yoshida T, Marusyk A, Beck AH, Polyak K, Toker A. Targeting Akt3 signaling in triplenegative breast cancer. Cancer Res. 2014; 74:964-973. [PubMed: 24335962]

Cho H, Mu J, Kim JK, Thorvaldsen JL, Chu Q, Crenshaw EB 3rd, Kaestner KH, Bartolomei MS, Shulman GI, Birnbaum MJ. Insulin resistance and a diabetes mellitus-like syndrome in mice lacking the protein kinase Akt2 (PKB beta). Science. 2001; 292:1728-1731. [PubMed: 11387480]

Cross DA, Alessi DR, Cohen P, Andjelkovich M, Hemmings BA. Inhibition of glycogen synthase kinase-3 by insulin mediated by protein kinase B. Nature. 1995; 378:785-789. [PubMed: 8524413]

Dan HC, Cooper MJ, Cogswell PC, Duncan JA, Ting JP, Baldwin AS. Akt-dependent regulation of NF- $\{$ kappa $\}$ B is controlled by mTOR and Raptor in association with IKK. Genes Dev. 2008; 22:1490-1500. [PubMed: 18519641]

Davies BR, Greenwood H, Dudley P, Crafter C, Yu DH, Zhang J, Li J, Gao B, Ji Q, Maynard J, Ricketts SA, Cross D, Cosulich S, Chresta CC, Page K, Yates J, Lane C, Watson R, Luke R, Ogilvie D, Pass M. Preclinical pharmacology of AZD5363, an inhibitor of AKT: pharmacodynamics, antitumor activity, and correlation of monotherapy activity with genetic background. Mol Cancer Ther. 2012; 11:873-887. [PubMed: 22294718]

De Marco C, Malanga D, Rinaldo N, De Vita F, Scrima M, Lovisa S, Fabris L, Carriero MV, Franco R, Rizzuto A, Baldassarre G, Viglietto G. Mutant AKT1-E17K is oncogenic in lung epithelial cells. Oncotarget. 2015

Diehl JA, Cheng M, Roussel MF, Sherr CJ. Glycogen synthase kinase-3beta regulates cyclin D1 proteolysis and subcellular localization. Genes Dev. 1998; 12:3499-3511. [PubMed: 9832503]

Dillon RL, Marcotte R, Hennessy BT, Woodgett JR, Mills GB, Muller WJ. Akt1 and akt2 play distinct roles in the initiation and metastatic phases of mammary tumor progression. Cancer Res. 2009; 69:5057-5064. [PubMed: 19491266]

Dummler B, Hemmings BA. Physiological roles of PKB/Akt isoforms in development and disease. Biochem Soc Trans. 2007; 35:231-235. [PubMed: 17371246] 
Eichhorn PJ, Gili M, Scaltriti M, Serra V, Guzman M, Nijkamp W, Beijersbergen RL, Valero V, Seoane J, Bernards R, Baselga J. Phosphatidylinositol 3-kinase hyperactivation results in lapatinib resistance that is reversed by the mTOR/phosphatidylinositol 3-kinase inhibitor NVP-BEZ235. Cancer Res. 2008; 68:9221-9230. [PubMed: 19010894]

Franke TF, Yang SI, Chan TO, Datta K, Kazlauskas A, Morrison DK, Kaplan DR, Tsichlis PN. The protein kinase encoded by the Akt proto-oncogene is a target of the PDGF-activated phosphatidylinositol 3-kinase. Cell. 1995; 81:727-736. [PubMed: 7774014]

Frias MA, Thoreen CC, Jaffe JD, Schroder W, Sculley T, Carr SA, Sabatini DM. mSin1 is necessary for Akt/PKB phosphorylation, and its isoforms define three distinct mTORC2s. Curr Biol. 2006; 16:1865-1870. [PubMed: 16919458]

Garofalo RS, Orena SJ, Rafidi K, Torchia AJ, Stock JL, Hildebrandt AL, Coskran T, Black SC, Brees DJ, Wicks JR, McNeish JD, Coleman KG. Severe diabetes, age-dependent loss of adipose tissue, and mild growth deficiency in mice lacking Akt2/PKB beta. J Clin Invest. 2003; 112:197-208. [PubMed: 12843127]

Garrett JT, Olivares MG, Rinehart C, Granja-Ingram ND, Sanchez V, Chakrabarty A, Dave B, Cook RS, Pao W, McKinely E, Manning HC, Chang J, Arteaga CL. Transcriptional and posttranslational up-regulation of HER3 (ErbB3) compensates for inhibition of the HER2 tyrosine kinase. Proc Natl Acad Sci U S A. 2011; 108:5021-5026. [PubMed: 21385943]

Gera JF, Mellinghoff IK, Shi Y, Rettig MB, Tran C, Hsu JH, Sawyers CL, Lichtenstein AK. AKT activity determines sensitivity to mammalian target of rapamycin (mTOR) inhibitors by regulating cyclin D1 and c-myc expression. J Biol Chem. 2004; 279:2737-2746. [PubMed: 14576155]

Gewinner C, Wang ZC, Richardson A, Teruya-Feldstein J, Etemadmoghadam D, Bowtell D, Barretina J, Lin WM, Rameh L, Salmena L, Pandolfi PP, Cantley LC. Evidence that inositol polyphosphate 4-phosphatase type II is a tumor suppressor that inhibits PI3K signaling. Cancer Cell. 2009; 16:115-125. [PubMed: 19647222]

Grabinski N, Mollmann K, Milde-Langosch K, Muller V, Schumacher U, Brandt B, Pantel K, Jucker M. AKT3 regulates ErbB2, ErbB3 and estrogen receptor alpha expression and contributes to endocrine therapy resistance of ErbB2(+) breast tumor cells from Balb-neuT mice. Cell Signal. 2014; 26:1021-1029. [PubMed: 24463007]

Han, HS. A phase I study of the AKT inhibitor (MK-2206) with concurrent trastuzumab and lapatinib in patients with HER2-positive solid tumors. J Clin Oncol; ASCO Annual Meeting; 2011. p. abstr 3028

Han HS, Swanton C, Janjigian YY, Sutherland SC, Chandarlapaty S, Lehman R, Hamilton N, Knowles J, Lee R, Yan L, Sullivan D, Hudis C. A phase I study of the AKT inhibitor (MK-2206) with concurrent trastuzumab and lapatinib in patients with HER2-positive solid tumors. J Clin Oncol. 2011; 29(suppl):abstr 3028.

Huang, A. Single agent activity of PIK3CA inhibitor BYL719 in a broad cancer cell line panel. Cancer Res; AACR 103rd Annual Meeting; 2012; 2012. p. 15

Hurtado A, Holmes KA, Geistlinger TR, Hutcheson IR, Nicholson RI, Brown M, Jiang J, Howat WJ, Ali S, Carroll JS. Regulation of ERBB2 by oestrogen receptor-PAX2 determines response to tamoxifen. Nature. 2008; 456:663-666. [PubMed: 19005469]

Hurvitz SA, Andre F, Jiang Z, Shao Z, Mano MS, Neciosup SP, Tseng LM, Zhang Q, Shen K, Liu D, Dreosti LM, Burris HA, Toi M, Buyse ME, Cabaribere D, Lindsay MA, Rao S, Pacaud LB, Taran T, Slamon D. Combination of everolimus with trastuzumab plus paclitaxel as first-line treatment for patients with HER2-positive advanced breast cancer (BOLERO-1): a phase 3, randomised, double-blind, multicentre trial. Lancet Oncol. 2015; 16:816-829. [PubMed: 26092818]

Jacinto E, Facchinetti V, Liu D, Soto N, Wei S, Jung SY, Huang Q, Qin J, Su B. SIN1/MIP1 maintains rictor-mTOR complex integrity and regulates Akt phosphorylation and substrate specificity. Cell. 2006; 127:125-137. [PubMed: 16962653]

Janiszewska M, Liu L, Almendro V, Kuang Y, Paweletz C, Sakr RA, Weigelt B, Hanker AB, Chandarlapaty S, King TA, Reis-Filho JS, Arteaga CL, Park SY, Michor F, Polyak K. In situ single-cell analysis identifies heterogeneity for PIK3CA mutation and HER2 amplification in HER2-positive breast cancer. Nat Genet. 2015; 47:1212-1219. [PubMed: 26301495]

Juric D, Castel P, Griffith M, Griffith OL, Won HH, Ellis H, Ebbesen SH, Ainscough BJ, Ramu A, Iyer G, Shah RH, Huynh T, Mino-Kenudson M, Sgroi D, Isakoff S, Thabet A, Elamine L, Solit 
DB, Lowe SW, Quadt C, Peters M, Derti A, Schegel R, Huang A, Mardis ER, Berger MF, Baselga J, Scaltriti M. Convergent loss of PTEN leads to clinical resistance to a PI(3)Kalpha inhibitor. Nature. 2015; 518:240-244. [PubMed: 25409150]

Kataoka Y, Mukohara T, Shimada H, Saijo N, Hirai M, Minami H. Association between gain-offunction mutations in PIK3CA and resistance to HER2-targeted agents in HER2-amplified breast cancer cell lines. Ann Oncol. 2010; 21:255-262. [PubMed: 19633047]

Kumar A, Purohit R. Cancer associated E17K mutation causes rapid conformational drift in AKT1 pleckstrin homology (PH) domain. PLoS One. 2013; 8:e64364. [PubMed: 23741320]

Kuo YC, Huang KY, Yang CH, Yang YS, Lee WY, Chiang CW. Regulation of phosphorylation of Thr-308 of Akt, cell proliferation, and survival by the B55alpha regulatory subunit targeting of the protein phosphatase 2A holoenzyme to Akt. J Biol Chem. 2008; 283:1882-1892. [PubMed: 18042541]

Landgraf KE, Pilling C, Falke JJ. Molecular mechanism of an oncogenic mutation that alters membrane targeting: Glu17Lys modifies the PIP lipid specificity of the AKT1 PH domain. Biochemistry. 2008; 47:12260-12269. [PubMed: 18954143]

Liang J, Zubovitz J, Petrocelli T, Kotchetkov R, Connor MK, Han K, Lee JH, Ciarallo S, Catzavelos C, Beniston R, Franssen E, Slingerland JM. PKB/Akt phosphorylates p27, impairs nuclear import of p27 and opposes p27-mediated G1 arrest. Nat Med. 2002; 8:1153-1160. [PubMed: 12244302]

Majewski IJ, Nuciforo P, Mittempergher L, Bosma AJ, Eidtmann H, Holmes E, Sotiriou C, Fumagalli D, Jimenez J, Aura C, Prudkin L, Diaz-Delgado MC, de la Pena L, Loi S, Ellis C, Schultz N, de Azambuja E, Harbeck N, Piccart-Gebhart M, Bernards R, Baselga J. PIK3CA mutations are associated with decreased benefit to neoadjuvant human epidermal growth factor receptor 2targeted therapies in breast cancer. J Clin Oncol. 2015; 33:1334-1339. [PubMed: 25559818]

Manning BD, Cantley LC. AKT/PKB signaling: navigating downstream. Cell. 2007; 129:1261-1274. [PubMed: 17604717]

Michalarea, V. "BEECH", a phase I/II study of the AKT inhibitor AZD5363 combined with paclitaxel in patients with advanced or metastatic breast cancer: results from the dose-finding study, including quantitative assessment of circulating tumor DNA as a surrogate for response/resistance. AACR. Proceedings of the 106th Annual Meeting of the American Association for Cancer Research; 2015. p. Abstract nr CT331

Morrow PK, Wulf GM, Ensor J, Booser DJ, Moore JA, Flores PR, Xiong Y, Zhang S, Krop IE, Winer EP, Kindelberger DW, Coviello J, Sahin AA, Nunez R, Hortobagyi GN, Yu D, Esteva FJ. Phase I/II study of trastuzumab in combination with everolimus (RAD001) in patients with HER2overexpressing metastatic breast cancer who progressed on trastuzumab-based therapy. J Clin Oncol. 2011; 29:3126-3132. [PubMed: 21730275]

Myers MP, Pass I, Batty IH, Van der Kaay J, Stolarov JP, Hemmings BA, Wigler MH, Downes CP, Tonks NK. The lipid phosphatase activity of PTEN is critical for its tumor supressor function. Proc Natl Acad Sci U S A. 1998; 95:13513-13518. [PubMed: 9811831]

Nagata Y, Lan KH, Zhou X, Tan M, Esteva FJ, Sahin AA, Klos KS, Li P, Monia BP, Nguyen NT, Hortobagyi GN, Hung MC, Yu D. PTEN activation contributes to tumor inhibition by trastuzumab, and loss of PTEN predicts trastuzumab resistance in patients. Cancer Cell. 2004; 6:117-127. [PubMed: 15324695]

Nakatani K, Thompson DA, Barthel A, Sakaue H, Liu W, Weigel RJ, Roth RA. Up-regulation of Akt3 in estrogen receptor-deficient breast cancers and androgen-independent prostate cancer lines. $\mathrm{J}$ Biol Chem. 1999; 274:21528-21532. [PubMed: 10419456]

Nanni P, Nicoletti G, Palladini A, Croci S, Murgo A, Ianzano ML, Grosso V, Stivani V, Antognoli A, Lamolinara A, Landuzzi L, di Tomaso E, Iezzi M, De Giovanni C, Lollini PL. Multiorgan metastasis of human HER-2+ breast cancer in Rag2-/-;I12rg-/- mice and treatment with PI3K inhibitor. PLoS One. 2012; 7:e39626. [PubMed: 22737248]

Nuciforo PG, Aura C, Holmes E, Prudkin L, Jimenez J, Martinez P, Ameels H, de la Pena L, Ellis C, Eidtmann H, Piccart-Gebhart MJ, Scaltriti M, Baselga J. Benefit to neoadjuvant anti-human epidermal growth factor receptor 2 (HER2)-targeted therapies in HER2-positive primary breast cancer is independent of phosphatase and tensin homolog deleted from chromosome 10 (PTEN) status. Ann Oncol. 2015; 26:1494-1500. [PubMed: 25851628] 
O’Reilly KE, Rojo F, She QB, Solit D, Mills GB, Smith D, Lane H, Hofmann F, Hicklin DJ, Ludwig DL, Baselga J, Rosen N. mTOR inhibition induces upstream receptor tyrosine kinase signaling and activates Akt. Cancer Res. 2006; 66:1500-1508. [PubMed: 16452206]

Parikh C, Janakiraman V, Wu WI, Foo CK, Kljavin NM, Chaudhuri S, Stawiski E, Lee B, Lin J, Li H, Lorenzo MN, Yuan W, Guillory J, Jackson M, Rondon J, Franke Y, Bowman KK, Sagolla M, Stinson J, Wu TD, Wu J, Stokoe D, Stern HM, Brandhuber BJ, Lin K, Skelton NJ, Seshagiri S. Disruption of PH-kinase domain interactions leads to oncogenic activation of AKT in human cancers. Proc Natl Acad Sci U S A. 2012; 109:19368-19373. [PubMed: 23134728]

Raught B, Peiretti F, Gingras AC, Livingstone M, Shahbazian D, Mayeur GL, Polakiewicz RD, Sonenberg N, Hershey JW. Phosphorylation of eucaryotic translation initiation factor 4B Ser422 is modulated by S6 kinases. EMBO J. 2004; 23:1761-1769. [PubMed: 15071500]

Sampath D. The PI3K inhibitor GDC-0032 enhances the efficacy of standard of care therapeutics in PI3K alpha mutant breast cancer models. American Association for Cancer Research. Cancer Res. 2013; 73(24 Suppl):Abstract nr P4-15-02.

Sangai T, Akcakanat A, Chen H, Tarco E, Wu Y, Do KA, Miller TW, Arteaga CL, Mills GB, Gonzalez-Angulo AM, Meric-Bernstam F. Biomarkers of response to Akt inhibitor MK-2206 in breast cancer. Clin Cancer Res. 2012; 18:5816-5828. [PubMed: 22932669]

Sarbassov DD, Guertin DA, Ali SM, Sabatini DM. Phosphorylation and regulation of Akt/PKB by the rictor-mTOR complex. Science. 2005; 307:1098-1101. [PubMed: 15718470]

Sergina NV, Rausch M, Wang D, Blair J, Hann B, Shokat KM, Moasser MM. Escape from HERfamily tyrosine kinase inhibitor therapy by the kinase-inactive HER3. Nature. 2007; 445:437-441. [PubMed: 17206155]

Serra V, Scaltriti M, Prudkin L, Eichhorn PJ, Ibrahim YH, Chandarlapaty S, Markman B, Rodriguez O, Guzman M, Rodriguez S, Gili M, Russillo M, Parra JL, Singh S, Arribas J, Rosen N, Baselga J. PI3K inhibition results in enhanced HER signaling and acquired ERK dependency in HER2overexpressing breast cancer. Oncogene. 2011; 30:2547-2557. [PubMed: 21278786]

Shah, PD. Phase I, open-label study evaluating the safety and tolerability of LJM716, BYL719 and trastuzumab in patients with metastatic HER2+ breast cancer. Cancer Res; Thirty-Seventh Annual CTRC-AACR San Antonio Breast Cancer Symposium; 2015. p. 5

Shin I, Yakes FM, Rojo F, Shin NY, Bakin AV, Baselga J, Arteaga CL. PKB/Akt mediates cell-cycle progression by phosphorylation of p27(Kip1) at threonine 157 and modulation of its cellular localization. Nat Med. 2002; 8:1145-1152. [PubMed: 12244301]

Shiota C, Woo JT, Lindner J, Shelton KD, Magnuson MA. Multiallelic disruption of the rictor gene in mice reveals that mTOR complex 2 is essential for fetal growth and viability. Dev Cell. 2006; 11:583-589. [PubMed: 16962829]

Slamon DJ, Clark GM, Wong SG, Levin WJ, Ullrich A, McGuire WL. Human breast cancer: correlation of relapse and survival with amplification of the HER-2/neu oncogene. Science. 1987; 235:177-182. [PubMed: 3798106]

Slamon DJ, Godolphin W, Jones LA, Holt JA, Wong SG, Keith DE, Levin WJ, Stuart SG, Udove J, Ullrich A, et al. Studies of the HER-2/neu proto-oncogene in human breast and ovarian cancer. Science. 1989; 244:707-712. [PubMed: 2470152]

Slamon DJ, Hurvitz SA, Chen D, Andre F, Tseng L-M, Jerusalem GHM, Wilks S, O'Regan R, Isaacs C, Toi M, Burris HA, He W, Riester M, Robinson D, Taran T, Gianni L. Predictive biomarkers of everolimus efficacy in HER2+ advanced breast cancer: Combined exploratory analysis from BOLERO-1 and BOLERO-3. J Clin Oncol. 2015; (suppl):abstr 512.

Stephens PJ, Tarpey PS, Davies H, Van Loo P, Greenman C, Wedge DC, Nik-Zainal S, Martin S, Varela I, Bignell GR, Yates LR, Papaemmanuil E, Beare D, Butler A, Cheverton A, Gamble J, Hinton J, Jia M, Jayakumar A, Jones D, Latimer C, Lau KW, McLaren S, McBride DJ, Menzies A, Mudie L, Raine K, Rad R, Chapman MS, Teague J, Easton D, Langerod A, Lee MT, Shen CY, Tee BT, Huimin BW, Broeks A, Vargas AC, Turashvili G, Martens J, Fatima A, Miron P, Chin SF, Thomas G, Boyault S, Mariani O, Lakhani SR, van de Vijver M, van 't Veer L, Foekens J, Desmedt C, Sotiriou C, Tutt A, Caldas C, Reis-Filho JS, Aparicio SA, Salomon AV, BorresenDale AL, Richardson AL, Campbell PJ, Futreal PA, Stratton MR. Oslo Breast Cancer C. The landscape of cancer genes and mutational processes in breast cancer. Nature. 2012; 486:400-404. [PubMed: 22722201] 
Sundqvist A, Bengoechea-Alonso MT, Ye X, Lukiyanchuk V, Jin J, Harper JW, Ericsson J. Control of lipid metabolism by phosphorylation-dependent degradation of the SREBP family of transcription factors by SCF(Fbw7). Cell Metab. 2005; 1:379-391. [PubMed: 16054087]

Tao JJ, Castel P, Radosevic-Robin N, Elkabets M, Auricchio N, Aceto N, Weitsman G, Barber P, Vojnovic B, Ellis H, Morse N, Viola-Villegas NT, Bosch A, Juric D, Hazra S, Singh S, Kim P, Bergamaschi A, Maheswaran S, Ng T, Penault-Llorca F, Lewis JS, Carey LA, Perou CM, Baselga J, Scaltriti M. Antagonism of EGFR and HER3 enhances the response to inhibitors of the PI3KAkt pathway in triple-negative breast cancer. Sci Signal. 2014; 7:ra29. [PubMed: 24667376]

Thoreen CC, Chantranupong L, Keys HR, Wang T, Gray NS, Sabatini DM. A unifying model for mTORC1-mediated regulation of mRNA translation. Nature. 2012; 485:109-113. [PubMed: 22552098]

Tschopp O, Yang ZZ, Brodbeck D, Dummler BA, Hemmings-Mieszczak M, Watanabe T, Michaelis T, Frahm J, Hemmings BA. Essential role of protein kinase B gamma (PKB gamma/Akt3) in postnatal brain development but not in glucose homeostasis. Development. 2005; 132:2943-2954. [PubMed: 15930105]

Varga, A. Phase I expansion trial of an oral TORC1/TORC2 inhibitor (CC-223) in advanced solid tumors. J Clin Oncol; 2013 ASCO Annual Meeting; 2013. p. abstr 2606

Wallin JJ, Guan J, Prior WW, Lee LB, Berry L, Belmont LD, Koeppen H, Belvin M, Friedman LS, Sampath D. GDC-0941, a novel class I selective PI3K inhibitor, enhances the efficacy of docetaxel in human breast cancer models by increasing cell death in vitro and in vivo. Clin Cancer Res. 2012; 18:3901-3911. [PubMed: 22586300]

Yan Y, Serra V, Prudkin L, Scaltriti M, Murli S, Rodriguez O, Guzman M, Sampath D, Nannini M, Xiao Y, Wagle MC, Wu JQ, Wongchenko M, Hampton G, Ramakrishnan V, Lackner MR, Saura C, Roda D, Cervantes A, Tabernero J, Patel P, Baselga J. Evaluation and clinical analyses of downstream targets of the Akt inhibitor GDC-0068. Clin Cancer Res. 2013; 19:6976-6986. [PubMed: 24141624]

Yang J, Cron P, Good VM, Thompson V, Hemmings BA, Barford D. Crystal structure of an activated Akt/protein kinase B ternary complex with GSK3-peptide and AMP-PNP. Nat Struct Biol. 2002; 9:940-944. [PubMed: 12434148]

Yi KH, Axtmayer J, Gustin JP, Rajpurohit A, Lauring J. Functional analysis of non-hotspot AKT1 mutants found in human breast cancers identifies novel driver mutations: implications for personalized medicine. Oncotarget. 2013; 4:29-34. [PubMed: 23237847]

Zhou BP, Liao Y, Xia W, Spohn B, Lee MH, Hung MC. Cytoplasmic localization of p21Cip1/WAF1 by Akt-induced phosphorylation in HER-2/neu-overexpressing cells. Nat Cell Biol. 2001; 3:245252. [PubMed: 11231573] 


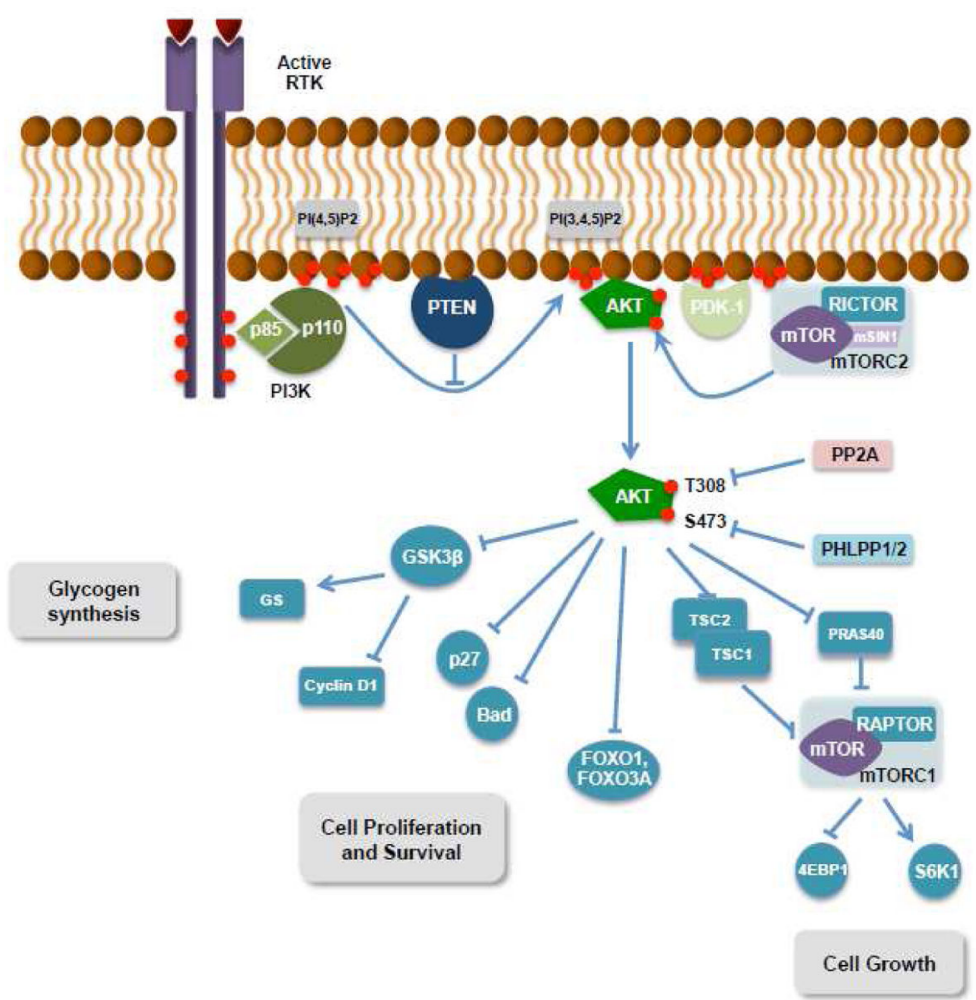

Figure 1.

Overview of the PI3K/AKT/mTOR pathway and cellular processes controlled by downstream signaling. RTK, tyrosine-kinase receptor; 4EBP1, eukaryotic initiation factor 4E-binding protein 1; TSC, tuberous sclerosis protein; GS, glycogen synthase. Red circles represent phosphate groups. 
A.

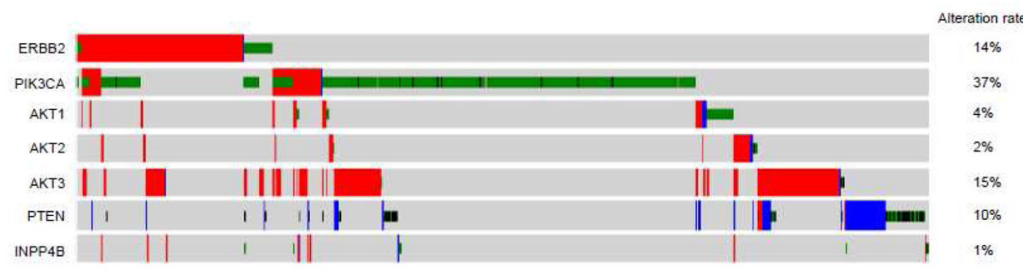

- Missense mutation "Amplification

- Truncating mutation - Deep deletion

B.

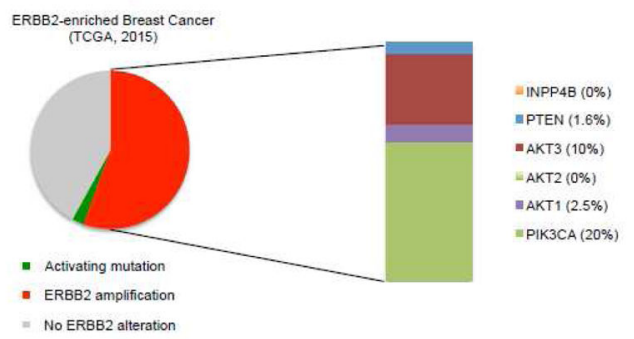

Figure 2.

Mutational landscape of regulators of the PI3K/AKT pathway in breast cancer. A. Copynumber and mutational data on ERBB2, PIK3CA, AKT 1-3 and phosphatases PTEN and INPP4B in breast cancer (TCGA, 2015). B. Mutation rates of the genes encoding these components in ERBB2-amplified breast cancer show that, after PI3K coding-gene, the gene encoding AKT3 is the most frequently altered, mainly by means of copy number gain. 
A.

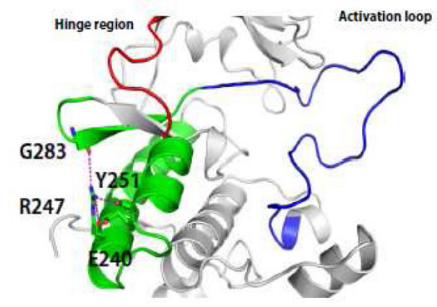

D.

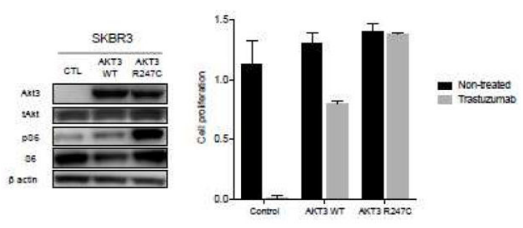

B.

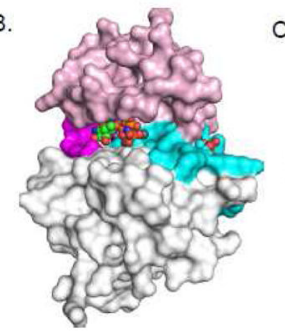

C

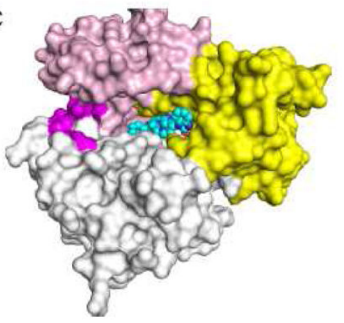

E.

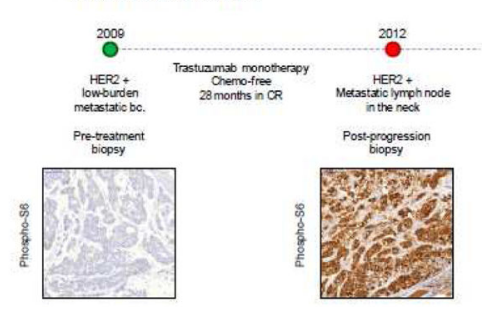

Figure 3.

A novel AKT3 bona fide gain-of-function mutation involved in resistance to trastuzumab monotherapy. A. Cartoon representation of the structure of AKT3 with regions involved in modulating functional conformational changes; residues R247 and those involved in establishing hydrogen bonds (dashed lines) are highlighted in stick representation. B. Structural model of AKT3 built based on homology with AKT1 (88\% sequence similarity with the kinase domain and $85 \%$ sequence similarity with the $\mathrm{PH}$ domain) using the crystal structures of the active state (PDB code 3CQU resolved at 2.2A; the active state does not contain the PH domain) and the inactive state (PDB code 3096 resolved at 2.7A). AKT3 in its active state with the ATP shown on the left and the phosphorylated Tyr shown on the right. C. AKT3 in its inactive state with the allosteric inhibitor ICQ shown in spheres bound between the kinase and the PH domains. The domains are colored as: pink for the Nterminal lobe, grey for the C-terminal lobe, magenta for the hinge region, cyan for the activation loop and yellow for the $\mathrm{PH}$ domain. The activation loop is not highlighted in the inactive state for clarity. D. Transduction of $\mathrm{AKT} 3^{\mathrm{R} 247 \mathrm{C}}$ and $\mathrm{AKT} 3^{\mathrm{WT}}$ coding vectors in ERBB2-amplified SkBr-3 cells. AKT3 ${ }^{\text {R247C }}$ enhances mTORC1 signaling (left panel) and increases resistance to trastuzumab as seen in colony-formation assays comparing cell proliferation of control, $\mathrm{AKT} 3^{\mathrm{WT}}$ and $\mathrm{AKT} 3^{\mathrm{R} 247 \mathrm{C}}$ transfected cells in the presence of the drug over 7 days. E. The ERBB2-amplified breast cancer patient experienced tumor progression after 28 months in complete response and showed re-activation of mTORC1 activity concurrent with the acquisition of the $\mathrm{AKT} 3^{\mathrm{R} 247 \mathrm{C}}$ mutation. 


\section{Table 1}

Inhibitors of the PI3K/AKT/mTOR pathway currently under clinical development for breast cancer. HR, hormone receptor; $\mathrm{MBC}$, metastatic breast cancer; TNBC triple negative breast cancer; $\mathrm{AR}$, androgen receptor. Information retrieved from clinicaltrials.gov.

\begin{tabular}{|c|c|c|}
\hline Agent & Activity & Phase of clinical development \\
\hline Everolimus & mTORC1 allosteric inh. & Approved \\
\hline Temsirolimus & mTORC1 allosteric inh. & Approved \\
\hline BEZ235 & $\mathrm{PI} 3 \mathrm{~K} / \mathrm{mTOR}$ & $\begin{array}{l}\text { Phase II in HER } 2+\text { patients failing to prior trastuzumab, and in } \mathrm{HR}+\text { in combination } \\
\text { with endocrine treatment }\end{array}$ \\
\hline GDC-0980 & $\mathrm{PI} 3 \mathrm{~K} / \mathrm{mTOR}$ & Phase II in combination with endocrine therapy \\
\hline Buparlisib (BKM120) & Pan-class I PI3K & $\begin{array}{l}\text { Phase III in combination with endocrine treatment in HR+/HER2-; in combination } \\
\text { with BYL719 in MBC; in TNBC; and in combination with neoadjuvant trastuzumab } \\
\text { in HER2+ patients }\end{array}$ \\
\hline Pictilisib (GDC-0941) & Pan-class I PI3K & Phase II in $\mathrm{HR}+$ in combination with endocrine treatment \\
\hline GDC-0032 & PI3K p110a, $\delta$, and $\gamma$ inhibitor & $\begin{array}{l}\text { Phase I with anti-HER } 2 \text { treatment in HER } 2+\text { patients; Ib/II with enzatulamide in AR } \\
+ \text { TNBC patients; and III in combination with endocrine therapy in HR+/HER2- } \\
\text { patients }\end{array}$ \\
\hline BYL719 & PI3K p110a & $\begin{array}{l}\text { Phase I in combination with T-DM1 in HER } 2+\text { patients progressing to trastuzumab; } \\
\text { and II in monotherapy in patients harboring alterations on the PI } 3 \mathrm{~K} \text { pathway, or in } \\
\text { combination with endocrine therapy }\end{array}$ \\
\hline MK-2206 & $\mathrm{AKT}$ & Phase II in combination with endocrine therapy in $\mathrm{HR}+$ patients \\
\hline GDC-0068 & AKT & Phase II in TNBC \\
\hline AZD5363 & AKT & Phase I/II in combination with endocrine therapy in HR+ patients \\
\hline
\end{tabular}

